\title{
HAK ATAS AKSESIBILITAS OBAT PATEN BAGI MASYARAKAT
}

\author{
LIDYA SHERY MUIS \\ Fakultas Hukum Universitas Airlangga \\ Jalan Darmawangsa Dalam Selatan, Airlangga, Gubeng \\ Kota Surabaya 60286, Indonesia \\ lidyasherymuis@gmail.com
}

\begin{abstract}
The right to accessibility of patent drugs is a constitutional right of citizens as the right to health guaranteed in Article 28H paragraph (1) of the 1945 Constitution of the Republic of Indonesia. But in relation to the rights to patent drugs that give rewards to inventors within a certain period of time to produce, distribute, economically exploiting and prohibiting third parties from producing it, has a negative effect, namely the limitation of public accessibility to patent drugs. The main issues to be studied are how to ratio the rights to the accessibility of patent drugs to the public and how to compare the rights to access drugs for the community in international agreements and patent regulations in Indonesia. The method used is normative juridical. The results showed that patent drug monopoly resulted in the right to accessibility of patent drugs to the public increasingly out of control because the price of patent drugs was very expensive, because that in reality TRIPs were more dominant protecting the rights of developed countries as holders of patent drugs, even though the Doha Declaration was born to protect public health rights due to the difficulty of access to drugs and the price of expensive drugs.
\end{abstract}

Keywords : Accessibilty, Right, The Paten of Drugs.

\begin{abstract}
Abstrak
Hak atas aksesibilitas obat paten merupakan hak konstitusional Warga Negara sebagai hak atas kesehatan yang dijamin dalam Pasal 28H ayat (1) UUD NRI tahun 1945. Namun dalam kaitannya dengan hak atas obat paten yang memberi reward kepada penemunya dalam jangka waktu tertentu untuk memproduksi, mendistribusikan, mengeksploitasi secara ekonomis dan melarang pihak ketiga untuk memproduksinya, telah memberi efek negatif yaitu dibatasinya aksesibilitas publik atas obat paten. Masalah pokok yang akan dikaji adalah bagaimana ratio legis hak atas aksesibilitas obat paten bagi masyarakat dan bagaimana perbandingan hak atas akses obat bagi masyarakat dalam perjanjian Internasional dan Peraturan paten di Indonesia. Metode yang digunakan adalah yuridis normatif. Hasil penelitian menunjukkan bahwa monopoli obat paten mengakibatkan hak atas aksesibilitas obat paten bagi masyarakat semakin tidak terkontrol karena harga obat paten yang sangat mahal, dikarenakan bahwa pada realitanya TRIPs lebih dominan melindungi hak negara maju sebagai pemegang hak atas obat Paten, meskipun ada Deklarasi Doha yang di lahirkan untuk melindungi hak kesehatan masyarakat dikarenakan sulitnya akses obat dan harga obat yang mahal.
\end{abstract}

Kata Kunci : Aksesibilitas, Hak, Obat Paten.

\section{A. Pendahuluan}

Obat merupakan salah satu bagian penting dalam terjaminnya kesehatan masyarakat. Pemerintah bertanggung jawab atas ketersediaan, pemerataan, dan keterjangkauan perbekalan kesehatan masyarakat. Obat terbagi menjadi dua yaitu obat paten dan obat generik. Obat paten adalah obat baru yang ditemukan berdasarkan riset 
industri farmasi yang diberi hak paten untuk memproduksi dan memasarkannya setelah melalui berbagai tahapan uji klinis dan proses pendaftaran paten di Dirjen HKI. Obat generik adalah obat yang telah habis masa berlaku patennya sehingga dapat diproduksi oleh semua perusahaan farmasi tanpa perlu membayar royalti. ${ }^{1}$

Obat paten merupakan bagian dari Hak Kekayaan Intelektual yang kemudian disebut HKI yang dalam kerangka ini masuk dalam kategori Hak Kekayaan Perindustrian. Pengaturan mengenai paten di Indonesia telah mengalami empat kali perubahan yaitu UU No. 6 Tahun 1989 dirubah menjadi UU No. 1 Tahun 1997, dirubah lagi menjadi UU No. 14 Tahun 2001 dan terakhir dirubah menjadi UU No. 13 Tahun 2016. ${ }^{2}$ Berdasarkan pada pasal 1 angka 1 UU No. 13 Tahun 2016 tentang Paten yang kemudian disingkat dengan UUP, menyebutkan Paten adalah hak eksklusif yang diberikan oleh negara kepada inventor atau hasil invensi dibidang teknologi untuk jangka waktu tertentu melaksanakan sendiri invensi tersebut atau memberikan persetujuan kepada pihak lain untuk melaksanakannya. Hak paten bersifat eksklusif karena hanya inventor yang menghasilkan invensi yang dapat diberikan hak, inventor dapat melaksanakan sendiri invensinya tersebut dengan memberi persetujuan kepada pihak lain untuk melaksanakan lisensi. ${ }^{3}$

Paten memberikan hak eksklusif kepada pemegangnya untuk melaksanakan sendiri invensinya dalam jangka waktu tertentu atau memberikan persetujuannya kepada pihak lain untuk melaksanakannya. Invensi yang dapat diberikan paten adalah invensi dalam bidang teknologi yang baru, mengandung langkah inventif dan dapat diterapkan dalam industri.Salah satu penemuan yang dapat dipatenkan adalah obatobatan modern. Produsen obat-obatan modern mengeluarkan biaya riset dan pengembangan (R\&D) yang tidak sedikit untuk membuat obat-obatan yang menyembuhkan berbagai penyakit. Paten atas obat-obatan tersebut menjamin bahwa biaya R\&D yang dikeluarkan oleh produsen akan dapat ditutupi selama jangka waktu perlindungan patennya yaitu selama dua puluh tahun. Selama jangka waktu perlindungan paten tersebut, produsen atau pemegang paten atas obat-obatan tersebut

\footnotetext{
${ }^{1}$ Nanang Yunarto, Revitalisasi Obat Generik: Hasil Uji Disolusi Obat Generik Tidak Kalah Dengan Obat Bermerek, Media Litbang Kesehatan Volume XX Nomor 4 Tahun 2010, h. 199.

2 OK Saidin, Aspek bukum Hak Kekayaan Intelektual (intellectual Property Rights), PT. Raja Grafindo Persada, Jakarta, 2015, h. 349.

${ }^{3}$ Ibid, h. 50.
} 
berhak untuk memproduksi, mendistribusikan, mengeksploitasi secara ekonomis dan melarang pihak ketiga yang tidak diberi izin untuk memproduksi obat-obatan tersebut. Walaupun bertujuan positif memberikan reward kepada penemunya, paten memiliki efek negatif meningkatkan harga dan membatasi akses publik dari obat-obatan tersebut.

Pada tingkat internasional, ancaman paten terhadap akses kesehatan publik bertambah nyata ketika World Trade Organization (WTO) memasukkan HKI sebagai salah satu perjanjian yang harus diikuti oleh negara-negara pesertanya. The Agreement on Trade-Related Aspects of Intellectual Property Rights (TRIPs) adalah perjanjian internasional di bawah administrasi WTO yang menetapkan standar minimum untuk berbagai peraturan HKI, termasuk paten, di masing-masing negara anggotanya. ${ }^{4}$ Penerapan TRIPs pada semua negara anggota W'TO menimbulkan perdebatan sengit pada awal pembentukan TRIPs karena level ekonomi dan pembangunan yang berbeda antara negara kaya dan miskin.TRIPs mewajibkan seluruh negara anggotanya untuk membuat aturan-aturan mengenai Hak Kekayaan Intelektual. ${ }^{5}$ TRIPs Agreement mensyaratkan adanya keseimbangan antara hak pemegang paten dengan kewajiban kepada masyarakat dengan cara tiap negara dapat menyesuaikan syarat-syarat tersebut dalam peraturan pelaksanaan nasionalnya masing-masing sepanjang tidak bertentangan dengan ketentuan yang berlaku di TRIPs.

Produsen obat-obatan modern, seperti Novartis dan Roche, kebanyakan berasal dari negara kaya. Sementara itu, kebanyakan pasien berasal dari negara-negara miskin yang berada di Asia, Amerika Latin, dan Afrika. Ketika sistem paten yang rumit dengan segala restriksinya diberlakukan, yang terjadi adalah sebuah ketidakadilan bagi negaranegara miskin. Pasien-pasien di negara miskin terbebani untuk membayar harga obat paten yang sering kali tidak sanggup mereka bayar.

Besarnya biaya penelitian, biaya pengembangan, studi-studi klinis, biaya promosi, biaya pengurusan paten, biaya produksi, biaya pemasaran dan biaya lainnya menjadi

\footnotetext{
${ }^{4}$ Ancaman Paten terhadap kesehatan Publik, Universitas Katolik Indonesia Atmajaya, https://m.atmajaya.ac.id/Web/KontenUnit.aspx?gid=artikel-hki\&ou=hki\&cid=ancaman-

paten-terhadap-kesehatan-publik-dan-safeguards-TRIPs, diakses pada tanggal 21 Juli 2018, pukul 21.00 W.I.B.

${ }^{5}$ Risa Amrikasari, Peran TRIPs dalam Perlindungan Kekayaan Intelektual, bttp:/ / www.bukumonline.com/klinik/ detail/ lt592407520f6f7/peran-TRIPs-iagreement-i-dalam-perrlindunganhak-kekayaan-intelektual, diakses pada tanggal 16 September 2018, pukul 07.25 W.I.B.
} 
salah satu alasan mahalnya harga obat paten. Mahalnya harga obat paten berakibat pada daya beli dan tingkat kesehatan masyarakat. Masyarakat harus menyisihkan penghasilannya untuk biaya pengobatan. Komponen biaya obat di Indonesia bisa mencapai empat puluh lima persen dari total biaya kesehatan. Studi yang dilakukan oleh WHO terhadap beberapa penduduk negara berkembang termasuk Indonesia, mengungkap adanya efek memiskinkan dari membeli obat. menurut survei Health Action International terhadap harga beberapa jenis obat di dunia, untuk membeli obat paten jenis Ciprofloxacin orginitator, masyarakat harus mengeluarkan uang setara dengan penghasilan mereka bekerja selama sepuluh hari. ${ }^{6}$

Pendistribusian obat paten yang tidak merata pun menjadi salah satu alasan keterbatasan masyarakat untuk mengakses obat paten. Hal ini tidak sesuai dengan pasal 28H ayat (1) Undang-undang Dasar Negara Republik Indonesia Tahun 1945 kemudian disebut dengan UUD 1945 yang berbunyi "Setiap orang berhak untuk hidup sejahtera lahir dan batin, bertempat tinggal, dan mendapatkan lingkungan hidup yang baik dan sehat serta berhak memperoleh pelayanan masyarakat". Masyarakat akan semakin jauh dari kesejahteraan dan hidup sehat pasal 28H UUD 1945 ini tidak terwujud dengan sempurna.

Kebijakan pembangunan yang tidak berpihak pada rakyat dan kecenderungan pada ekonomi pasar sehingga yang kuat akan mampu mengakses sumber-sumber ekonomi produktif lebih banyak sedangkan rakyat kecil lebih dianggap sebagai obyek pembangunan sehingga dibiasakan untuk bersikap pasif dan pasrah menerima keadaaan. Konsekuensinya, kemiskinan dan ketimpangan sosial muncul sebagai akibat dari proses pembangunan ekonomi yang tidak merata. ${ }^{7}$

Berdasarkan pada uraian tersebut diatas, maka permasalahan pokok yang akan dikaji adalah bagaimana ratio legis hak atas aksesibilitas obat paten bagi masyarakat dan bagaimana perbandingan hak atas akses obat bagi masyarakat dalam perjanjian Internasional dan Peraturan paten di Indonesia.

${ }^{6}$ Titon Slamet Kurnia, Hak Atas Derajat Kesehatan Optimal Sebagai HAM di Indonesia, Alumni, Bandung, 2007, h. 2.

${ }^{7}$ Nunung Nuryartono dan Hendri Saparini, "Kesenjangan Ekonomi Sosial dan Kemiskinan", Ekonomi Konstitusi: Haluan Baru Kebangkitan Ekonomi Indonesia, eds. Soegeng Sarjadi dan Iman Sugema, Jakarta, Soegeng Sarjadi Syndicate, 2009, h. 283-284. 


\section{B. Telaah Konsep}

\section{Paten}

Obat paten dilindungi oleh Undang-undang Paten yang merupakan hak eksklusif yang diberikan oleh negara kepada inventor atas hasil invensinya di bidang teknologi untuk jangka waktu tertentu melaksanakan sendiri invensinya tersebut atau memberikan persetujuan kepada pihak lain untuk melaksanakannya. Menurut Marzuki, fungsi utama paten adalah untuk melindungi penemuan karena penemuan bernilai ekonomis. ${ }^{8}$ Paten yang telah di publikasi mendapatkan perlindungan hukum dari UUP dalam suatu jangka waktu yang telah ditentukan yaitu 20 tahun, dengan demikian membuka kesempatan kepada pihak ketiga untuk memamfaatkan penemuan yang dipublikasikan itu.

Pengaturan paten merupakan bentuk perlindungan terhadap penemuan yang memenuhi syarat patentable yakni novelty, inventive step, dan applicable, ${ }^{9}$ sedangkan yang dilindungi Undang-undang Paten adalah klaim penemuan yaitu siapa yang terlebih dahulu mendaftarkan paten. ${ }^{10}$ Tiga bentuk penemuan dan akibat yang ditimbulkan oleh hak paten adalah (1) penemuan sebuah produk, (2) Penemuan sebuah proses, (3) penemuan sebuah proses untuk menghasilkan sebuah produk; ditentukan tergantung pada perbedaan dari ketiga bentuk deskriptif penemuan tersebut. ${ }^{11}$

Untuk pemerintah Indonesia, perlindungan paten farmasi merupakan masalah kesehatan masyarakat yang serius. Kebijakan untuk melindungi paten farmasi harus seimbang dengan perjanjian TRIPs dan tujuannya menyediakan obat yang lebih murah kecuali pemerintah memberikan perlindungan yang memadai untuk paten farmasi. Indonesia perlu mengurangi biaya obat-obatan yang mendesak karena empat alasan. Pertama, anggaran pemerintah untuk obat terbatas. Kedua, tingkat penjualan obat generik rendah. Ketiga, keterbatasan penyakit kronis dan masalah yang muncul. Keempat, harga obat karena perlindungan paten farmasi telah meningkat. Situasi itu disebabkan oleh kegagalan pemerintah Indonesia untuk memaksimalkan sejumlah tahun 1999

${ }^{8}$ Peter Mahmud Marzuki, Luasnya Perlindungan Paten, Jurnal Hukum, UII, Vol. 6 No. 12,

${ }^{9}$ Rachmadi Usman, Hukum Hak atas Kekayaan Intelektual : Perlindungan dan Dimensi Hukumnya di Indonesia, Alumni, Bandung, 2003, h.214.

${ }^{10}$ Arianne Astrinia dan Brian Amy Prasetyo, Perbandingan Konsep Pelanggaran Paten di Indonesia dan Amerika Serikat: Studi Kasus Pelanggarna Paten Obat, Jurnal Hukum FH UI, 2014, h. 10.

${ }^{11}$ Mastur, Perlindungan Hukum Hak Kekayaan Intelektual Dibidang Paten, Jurnal Ilmiah Ilmu Hukum QISTI Vol 6 No. 1 Januari 2012,h. 68. 
pengaman yang dimasukkan dalam perjanjian TRIPs. Hal ini disebabkan oleh pemerintah dan tidak adanya tindakan yang tidak jelas dan sifat fleksibel. ${ }^{12}$

\section{Teori Keadilan}

Keadilan bagi Plato suatu perbuatan yang baik menolak undang-undang diskriminatif, dan dengan itu membela keadilan, merupakan subjek mendapatkan manfaat praktis dari itu atau tidak. Keadilan merupakan nilai yang harus dibela tanpa harus dilihat apakah pembelaan terhadap keadilan secara konkret memberi manfaat pada pembelaan atau tidak. Keadilan harus menjadi watak manusia, orang baik adalah orang yang mampu bertindak adil. Hukum yang harus ditaati demi keadilan itu bagi dalam hukum alam positif. ${ }^{13}$

Menurut Theo Huijbers, hukum harus terjalin erat dengan keadilan, hukum adalah undang-undang yang adil bila suatu hukum konkrit, yakni undang-undang yang bertentangan dengan prinsip-prinsip keadilan, makna hukum itu tidak bersifat normatif lagi dan tidak dapat dikatakan hukum lagi. Undang-undang hanya dapat menjadi hukum bila memenuhi prinsip-prinsip keadilan. Adil merupakan unsur konstitusif segalam pengertian tentang hukum. ${ }^{14}$

Hukum dibuat oleh negara untuk memenuhi rasa keadilan dan menciptakan kesejahteraan bagi warganya. Hal ini tercermin dalam pembukaan UUD 1945 menggunakan perkataan "Kesejahteraan Umum". Pertama-tama negara wajib memajukan kesejahteraan umum dengan menciptakan suatu basis kemakmuran bagi seluruh rakyat. Kemakmuran dimaksudkan ialah suatu keadaan dimana kebutuhan manusia dapat dipenuhi dengan wajar secara mantap atau terus menerus.

Pandangan-pandangan Aristoteles tentang keadilan ditujukan bagi keadilan yang berdasarkan filsafat umum Aristoteles, mesti dianggap sebagai inti dari filsafat hukumnya, "karena hukum hanya bisa ditetapkan dalam kaitannya dengan keadilan". ${ }^{15}$ Sangat penting dari pandangannya ialah pendapat bahwa keadilan mesti dipahami dalam pengertian kesamaan. Namun Aristoteles membuat pembedaan penting antara kesamaan numerik dan proposional. Kesamaan numerik

${ }^{12}$ Ibid.

${ }^{13}$ Muhammad Syukri Albani Nasution, dkk, Hukum Dalam Pendekatan Filsafat, Kencana, Jakarta, 2016, h.31.

${ }^{14}$ Theo Huijbers, Filsafat Hukum Dalam Lintas Sejarah, Kanisius, Yogyakarta, 1990, h.70.

${ }^{15}$ Carl Joachim Friedrich, Filsafat Hukum: Perspektif Historis, Nuansa, Bandung, 2004, h. 24. 
mempersamakan setiap manusia sebagai satu kesatuan. Inilah yang sekarang bisa kita pahami tentang kesamaan dan yang dimaksud bahwa semua warga adalah sama didepan hukum. Kesamaan proporsional memberi tiap orang apa yang menjadi haknya sesuai dengan kemampuannya, prestasinya, dan sebagainya. Pembedaan oleh aristoteles menimbulkan banyak kontroversi dan perdebatan seputar keadilan. Keadilan dibedakan menjadi jenis keadilan distributif dan korektif. Keadilan distributif dan korektif sama-sama rentan terhadap problema kesamaan atau kesetaraan dan hanya bisa dipahami dalam kerangkanya. ${ }^{16}$

a) Teori keadilan hak atas kesehatan menurut John Rawls

Teori keadilan John Rawls, yang dianggap sebagai penyangkalan kontemporer atas teori etika egaliter, membahas masalah distribusi barang sosial yang adil. Meskipun Rawls tidak membahas hak atas kesehatan dalam teorinya, upaya untuk memperbesar teori untuk mencakup konsep kesehatan semakin maju. Tujuan pertama dari teori Rawls adalah untuk mencapai komunitas yang tertata dengan baik dan dikelola dengan baik melalui pembentukan sistem distribusi sosial yang adil. Dia menekankan perlunya memfokuskan pada keadilan daripada keadilan absolut dari distribusi. . Rawls menyarankan bahwa individu akan dapat mengejar tujuan mereka sendiri dan mewujudkan rencana kehidupan rasional mereka dalam komunitas yang tertata dengan baik dan dikelola dengan baik. Rawls mengembangkan gagasan ini dengan mengikuti wacana kontrak sosial yang diajukan oleh John Locke, Jan Jacques Rousseau dan Immanuel Kant pada abad ke-17 dan ke-18. Locke mengatakan bahwa otoritas politik muncul membentuk kontrak sosial antara yang dikelola dan administrator dengan kehadiran persetujuan sukarela dari yang dikelola. ${ }^{17}$

Aspek penting dari pandangan Rawls adalah bahwa keadilan dapat dicapai bukan dengan keadilan absolut tetapi dengan keadilan dan membenarkan klaimnya tergantung pada dua prinsip, yaitu :

1) Kebebasan yang setara yaitu setiap individu harus memiliki hak dasar yang sama. Kebebasan politik, kebebasan hati nurani, kebebasan berbicara dan berkumpul, kebebasan berekspresi, harga diri, integritas pribadi, hak

${ }^{16}$ Ibid.h. 25 .

${ }^{17}$ John Rawls, A Teory of Justice, Cambridge: The Belknap Press, 2005, h. 60. 
kepemilikan, hak untuk tidak ditangkap secara sewenang-wenang, kebebasan berpikir dianggap sebagai hak dasar. Rawls mengemukakan bahwa individuindividu pada posisi awal akan setuju bahwa adil untuk memiliki kesetaraan absolut untuk hak-hak dasar di antara individu-individu tersebut.. ${ }^{18}$

2) Ketimpangan sosial, "Prinsip perbedaan " yaitu Ketidaksetaraan pendapatan dan kesejahteraan dianggap adil jika dan hanya jika ketidaksetaraan ini untuk kepentingan yang terburuk". Langkah prinsip perbedaan ketika distribusi sumber daya keluar dari ruang lingkup prinsip pertama keadilan, seperti pendapatan dan kesejahteraan, dipertimbangkan dan tidak perlu ada kesetaraan absolut dari pendapatan dan kesejahteraan bagi masyarakat yang adil dengan ketentuan bahwa ketimpangan ini berfungsi untuk kepentingan yang paling miskin. ${ }^{19}$

Dalam teori keadilan, ada dua langkah menuju masyarakat yang adil. Langkah pertama adalah musyawarah prinsip-prinsip keadilan di posisi awal, dan langkah kedua adalah mempersiapkan undang-undang untuk membentuk sistem. Rawls mengklaim bahwa kesehatan membutuhkan pengetahuan yang kuat sehingga harus ditangani oleh orang yang memiliki keahlian itu. Karenanya undang-undang harus disiapkan oleh para ahli dalam kerangka prinsip-prinsip keadilan masyarakat yang adil. Bergantung pada argumen ini Rawls menempatkan kesehatan pada langkah kedua teori ini.Di sisi lain, saat ini sudah diketahui bahwa kesehatan adalah konsep yang lebih luas dari sekedar layanan kuratif atau rehabilitasi, dan tindakan dan layanan kesehatan masyarakat preventif yang mencakup faktor-faktor penentu sosial kesehatan memainkan peran besar untuk menjadi dan tetap sehat. Pengetahuan ini menciptakan keraguan kuat tentang argumen Rawls tentang kesehatan. Upaya untuk memperbesar teori Rawls untuk mencakup kesehatan sebagai subjek prinsip-prinsip keadilan muncul atas dasar ini. 2012, h.. 863

${ }^{18}$ Munson, R, Intervention and Refection Basic Issues in Bioethics. 9th. Boston: Cengage Learning, ${ }^{19}$ John Rawls, Fried, C, Sen, A, Schelling, TC, Liberty, Equality, and Law, 1st. Cambridge: Cambridge University Press, 1987. 
b) Teori keadilan hak atas kesehatan menurut Norman Daniels

Daniels memulai teorinya dengan mencari jawaban atas pertanyaan atas dasar etika di mana kewajiban kita untuk memberikan layanan kesehatan kepada orang-orang yang membutuhkannya? Paling sering pertanyaan ini ditangani dengan memfokuskan pada intervensi baru dalam kedokteran dan layanan kesehatan dan menentukan siapa yang harus memiliki akses ke layanan ini. Namun Daniels berpikir jawaban untuk pertanyaan tersebut harus muncul dari pandangan yang jauh lebih luas karena ada banyak faktor selain intervensi medis inovatif dan layanan kesehatan yang mempengaruhi status kesehatan individu dan populasi. Kita harus mempertimbangkan dampak dari keputusan sosial politik terhadap kesehatan ketika kita menangani hak atas kesehatan dan kewajiban serta tanggung jawab yang muncul dari hak ini. Atas dasar ini, ketika masalah ditangani atas dasar keadilan, distribusi sumber daya layanan sosial yang adil harus diperhitungkan. ${ }^{20}$

Pandangan ini Daniels mengatakan bahwa kita harus menangani kesehatan bersama dengan semua penentu sosial untuk mencapai status kesehatan yang diperlukan untuk fungsi normal spesies manusia. Oleh karena itu nilai etis dari layanan kesehatan dan penentu sosial kesehatan muncul dari peran penting mereka untuk memberikan individu kemampuan fungsi normal khusus untuk spesies manusia. Dengan kata lain, tanpa layanan ini individu mungkin tidak dapat memenuhi fungsi manusia. Fungsi normal secara etis penting karena memperlengkapi individu untuk memiliki kesempatan yang setara. Dengan demikian Daniels menempatkan kesehatan dan layanan yang terkait dengan kesehatan dalam posisi hierarkis etis yang lebih tinggi daripada barang sosial lainnya. Posisi ini menunjukkan bahwa nilai etis kesehatan dan penentu sosial kesehatan lebih besar daripada layanan sosial lainnya. ${ }^{21}$

\section{Teori Perlindungan Hukum}

Teori perlindungan hukum dari Telders, Van der Grinten dan Molengraff sebagaimana dikutip Misahardi Wilamarta menyebutkan bahwa suatu norma dapat dilanggar apabila suatu kepentingan yang dimaksud untuk dilindungi oleh norma itu

${ }^{20}$ Norman Daniels, Just Health., Cambridge: Cambridge University Press, 2009. h. 11.

${ }^{21}$ Ibid.,h. 140. 
dilanggar. Teori ini menjadi pegangan yang kuat untuk menolak suatu tuntutan dari seseorang yang merasa dirugikan kepentingannya oleh suatu perbuatan melanggar hukum. ${ }^{22}$ Prajudi Atmosudirjo menyebutkan bahwa tujuan perlindungan hukum adalah tercapainya keadilan. Fungsi hukum tidak hanya dalam upaya mewujudkan kepastian hukum saja, tetapi juga agar tercapainya jaminan dan keseimbangan yang sifatnya tidak sekedar adaptif dan fleksibel, akan tetapi berfungsi juga untuk menciptakan keseimbangan pengusaha dan konsumen, pemerintah dengan rakyat. Hukum sangat dibutuhkan untuk melindungi mereka yang lemah atau belum kuat secara sosial, ekonomi dan politik untuk memperoleh keadilan sosial. ${ }^{23}$ Unsur-unsur yang tercantum dalam definisi teori perlindungan hukum, meliputi : (a) Adanya wujud atau bentuk perlindungan atau tujuan perlindungan; (b) Subjek Hukum, dan (c) Objek perlindungan hukum. ${ }^{24}$

Menurut pendapat Phillipus M. Hadjon bahwa perlindungan hukum bagi rakyat sebagai tindakan pemerintah yang bersifat preventif dan represif. Perlindungan hukum yang preventif bertujuan untuk mencegah terjadinya sengketa, yang mengarahkan tindakan pemerintah bersikap hati-hati dalam pengambilan keputusan berdasarkan diskresi, dan perlindungan yang represif bertujuan untuk menyelesaikan terjadinya sengketa, termasuk penanganannya di lembaga peradilan. Perlindungan hukum adalah perlindungan harkat dan martabat, serta pengakuan terhadap hak-hak asasi manusia yang dimiliki oleh subjek hukum berdasarkan ketentuan hukum dan kesewenangan. ${ }^{25}$

Suatu negara pasti memiliki hubungan dengan warga negaranya. Hubungan inilah yang melahirkan hak dan kewajiban. Negara wajib memberikan perlindungan hukum bagi warga negaranya, dan warga negara wajib mendapatkan perlindungan hukum. Indonesia telah mengukuhkan dirinya sebagai negara hukum yang tercantum di dalam UUD 1945 Pasal 1 ayat 3 yang berbunyi "Indonesia adalah negara hukum". Perlindungan hukum menjadi unsur esensial serta menjadi konsekuensi dalam negara

${ }^{22}$ Mishardi Wilamarta, Hak Pemegang Saham Monoritas dalam Rangka Good Corporte Gorvernance, Program Pascasarjana Fakultas Hukum Universitas Indonesia, Jakarta, 2002, h.20.

${ }^{23}$ L.J. Van Apeldoorn, Pengantar Ilmu Hukum, diterjemahkan oleh Oetarid Sadino, Pradnya Paramitha, Jakarta, 2001, h.52.

${ }^{24}$ Salim dan Erlies Septiana Nurbani, Penerapan Teori Hukum Pada penelitian Tesis dan Disertasi, Raja Grafindo , Jakarta, 2000, h. 263.

25Phillipus M. Hadjon, Perlindungan Hukum Bagi Rakyat Indonesia, Bina Ilmu, Surabaya,1987. h. 29. (selanjutnyadisebut Phillipus M. Hadjon I) 
hukum, negara wajib menjamin hak-hak hukum warganya. Merumuskan prinsipprinsip perlindungan hukum Indonesia yang berlandaskan kepada pancasila sebagai ideologi dan falsafah negara.

\section{Metode Penelitian}

Metode yang digunakan adalah penelitian yuridis normatif atau disebut juga dengan penelitian doctrinal yaitu penelitian yang objek kajiannya adalah dokumen peraturan perundang-undangan dan bahan pustaka. ${ }^{26}$ Penelitian ini menggunakan data sekunder. Data sekunder merupakan bahan hukum yang diambil dari studi kepustakaan yang terdiri dari bahan hukum primer, bahan hukum sekunder dan bahan non hukum.

\section{Pembahasan}

\section{Ratio Legis Hak Atas Aksesbilitas Obat Paten Bagi Masyarakat}

Obat sebagai salah satu unsur penting dalam upaya kesehatan, mulai dari upaya peningkatan kesehatan, pencegahan, diagnosis, pengobatan dan pemulihan harus diusahakan agar selalu tersedia pada saat dibutuhkan. Obat unsur yang penting dalam upaya kesehatan masyarakat, obat juga sebagai produk dari industri farmasi dengan sendiri tidak lepas dari aspek ekonomi dan teknologi.

1. Hak Warga Negara atas Aksesbilitas Obat Paten

Dalam literatur berbahasa Inggris kerap kali dikemukakan bahwa hak berdasarkan hukum (legal right) dibedakan dari hak yang timbul dari norma lain. Menurut Paton, hak berdasarkan hukum biasanya diartikan sebagai hak yang diakui dan dilindungi oleh hukum. Menurut Jeremy Bentham, hak adalah anak dari hukum. Dari hukum yang nyata timbul hak yang nyata. Sebaliknya dari hukum yang imajiner yaitu hukum alam, timbul hak yang bersifat imajiner. Hak-hak alamiah benar-benar tidak masuk akal. Sebelum Bentham, David Hume juga berpendapat bahwa hukum alam dan hak-hak alamiah bersifat meta-fisis dan tidak nyata. Oleh karena itu Bentham berpendapat bahwa hukum yang nyata bukanlah hukum alam, melainkan hukum yang dibuat oleh lembaga legislatif. ${ }^{27}$

${ }^{26}$ Soejono dan H. Abdurrahman, 2003, Metode Penelitian Hukum, Rineka Cipta, Jakarta, h. 56

${ }^{27}$ Peter Mahmud Marzuki, Pengantar Ilmu Hukum, Kencana, Jakarta, 2016, h. 142. 
Menurut M.D.A Freeman terdapat dua teori mengenai HKI, yaitu teori kehendak yang menitikbetkan kepada kehendak atau pilihan dan lain teori kepentingan atau teori kemanfaatan. Kedua teori tersebut berkaitan dengan tujuan hukum. Teori kehendak dianut oleh mereka yang berpandangan bahwa tujuan hukum memberikan kebebasan apa yang dikehendakinya. Apa yang akan ia lakukan merupakan suatu pilhan. Dengan demikian, diskresi individu merupakan ciri khas paling menonjol dari konsep hak. Penganut teori kehendak pada dewasa ini adalah H.L.A. Hart. ${ }^{28}$

Hak dapat ditinjau dari beberapa segi yaitu hak orisinal dan hak derivatif, hak dasar, hak politik, hak privat, dan hak konstitusional. Hak atas kesehatan merupakan bagian dari hak Konstitusional karena merupakan hak dasar yang dituangkan dalam konstitusi tersebut sebagai hak konstitusional. Menurut Prof. Jimly Asshiddiqie, Hak konstitusional merupakan hak-hak yang dijamin dalam dan oleh Undang-Undang Dasar (UUD) 1945. Penjaminan hak tersebut baik dinyatakan secara tegas maupun secara tersirat. ${ }^{29} \mathrm{Hak}$ konstitusi berkaitan dengan hak warga negara.

\section{Kesehatan sebagai Hak Asasi Manusia}

HAM merupakan hak yang diperoleh saat kelahirannya sebagai manusia, maka HAM meliputi hak-hak yang apabila dicabut atau dikurangai akan mengakibatkan berkurang derajat kemanusiaannya. Hak dasar pertama adalah hak hidup yang membawa konsekuensi adanya hak-hak lain seperi hak mendapatkan kehidupan dan pekerjaan yang layak, hak berkeluarga dan melanjutkan keturunan, hak mendapatkan kewarganegaraan dan hak mengeluarkan pendapat, berserikat dan berkumpul.

Pasal 1 angka 1 Undang-undang Nomor 6 Tahun 2009 tentang Kesehatan selanjutnya disebut UU Kesehatan, Kesehatan adalah keadaan sehat, baik secara fisik, mental, spritual maupun sosial yang memungkinkan setiap orang untuk hidup produktif secara sosial dan ekonomis. Pasal 25 Universal Declaration of Human Rights (UDHR). Jaminan hak atas kesehatan juga terdapat dalam Pasal 12 ayat (1) Konvensi

${ }^{28}$ Lord Lloyd of Hampstead dan M.D.A. Freeman, An Introduction To Jurisprudence . London: English Language Book Society, 1985, Di kutip dari Peter Mahmud Marzuki, Ibid., h. 150.

${ }^{29}$ Jimly Asshiddiqie, Konstitusi \& Konstitusionalisme Indonesia, Edisi Revisi, Konstitusi Press, Jakarta, 2005, h. 343 
Internasional tentang Hak Ekonomi, Sosial dan Budaya yang ditetapkan oleh Majelis Umum PBB 2200 A (XXI) tanggal 16 Desember 1966, Instrumen internasional lain tentang hak atas kesehatan juga terdapat pada Pasal 12 dan 14 Konvensi Internasional tentang Penghapusan Semua Bentuk Diskriminasi terhadap Perempuan, dan ayat 1 Deklarasi Universal tentang Pemberantasan Kelaparan dan kekurangan Gizi. Pada lingkup nasional, Pasal 28 H ayat (1) UUD 1945 menyatakan bahwa setiap orang berhak hidup sejahtera lahir dan batin, bertempat tinggal, dan mendapatkan lingkungan hidup yang baik dan sehat serta berhak memperoleh pelayanan kesehatan. Pasal 9 UU Nomor 39 Tahun 1999 tentang Hak Asasi Manusia

\section{Prinsip Welfare State}

Welfare State adalah tanggung jawab negara terhadap kesejahteraan warganya. Definisi sederhana dari negara kesejahteraan adalah Bentuk pemerintahan yang demokratis itu menempatkan Negara sebagai institusi itu bertanggung jawab terhadap kesejahteraan rakyat, melalui serangkaian kebijakan publik di kebijakan ekonomi dan kebijakan sosial untuk pencapaian kesejahteraan dan keadilan sosial. ${ }^{30}$ Peranan pemeritah kepada kesejahteraan negara sangat luas sehingga membutuhkan mekanisme yang terkontrol untuk membatasi tindakan pemerintah agar tetap dalam lingkup tujuan negara dalam konstitusi. Konsep kesejahteraan negara lebih dipahami sebagai pengaruh terhadap sumber kesejahteraan pribadi warga negara sebagai bagian modal sosial. ${ }^{31}$

Philipus M. Hadjon berpendapat bahwa Indonesia menganut konsep negara kesejahteraan, sebenarnya tekad negara Indonesia untuk mewujudkan kesejahteraan umum bukan monopoli konsep welvarstaat. $^{32}$ Lebih lanjut Sjachran Basah mengemukakan bahwa jika adanya kewajiban pemerintahan untuk memajukan kesejahteraan umum untuk merupakan ciri konsep kesejahteraan, Indonesia tergolong sebagai negara kesejahteraan, karena tugas pemerintah tidaklah sematamata hanya di bidang pemerintahan saja, melainkan harus juga melaksanakan

\footnotetext{
${ }^{30}$ Aktieva Tri Tjitrawati, The Just Drug Distribution In The Perspective Of Welfare State, Mimbar Hukum, Volume 25, Nomor 3, Oktober 2013, h. 2

${ }^{31}$ Mikael Rostila, Social Capital an Health Inequality in European Welfare State, Palgrave Macmillan, 2013, London, h. 10, dalam Aktieva Tri Tjitrawati, The Just Drug Distribution In The Perspective Of Welfare State, Mimbar Hukum, Volume 25, Nomor 3, Oktober 2013. h. 3

${ }^{32}$ Philipus M. Hadjon, Perlindungan Bagi Rakyat di Indonesia, Edisi Revisi, Peradaban, Jakarta, 2007, h.91. (selanjutnyadisebut Phillipus M. Hadjon II)
} 
kesejahteraan sosial dalam rangka mencapai tujuan negara yang dijalani melalui pembangunan nasional. ${ }^{33}$

\section{Obat Sebagai Masalah Sosial}

Obat sebagai objek perlindungan paten selalu dilihat dari segi ekonomi. Sejarah terbentuknya TRIPs dilandasi keinginan negara industri kapitalis untuk menguasai pasar ekonomi dunia, dengan memaksakan berlakunya aturan standar hak milik intelektual di negara berkembang. Prakteknya banyak klausula dalam perjanjian lisensi yang merugikan pihak licensee dari segi ekonomi maupun teknologi. Hal inilah yang seharusnya tidak mempengaruhi paten obat karena bila paten obat dinilai dari segi ekonomi, produsen obat akan menaikkan harga setinggi-tingginya agar mendapatkan keuntungan yang besar. Jika hal ini terjadi Indonesia sebagai negara berkembang akan kesulitan mengendalikan harga obat. ${ }^{34}$

Salah satu masalah negara berkembang adalah dalam bidang ketersediaan obat khususnya obat esensial berupa obat untuk penyakit Malaria, Demam Berdarah, TBC, HIV/AIDS dan penyakit lainnya. Penyakit seperti ini membutuhkan penanganan cepat dan tepat karena bersifat menular. Penyakit menular harus ditangani secara hati-hati. Namun sangat disayangkan tidak banyak perusahaan obat Paten yang memproduksi obat untuk penyakit ini dikarenakan ttidak bersifat komersil dan penderita penyakit ini kebanyakan adalah masyarakat yang kurang mampu sehingga memiliki daya beli yang lemah. Perusahaan obat Paten merasa tidak akan mendapat keuntungan jika memproduksi obat untuk penyakit ini. Perusahaan obat lebih banyak memproduksi obat paten untuk penyakit yang diakibatkan oleh gaya hidup yang tidak sehat seperti stoke, obesitas, jantung, diabetes dan darah tinggi. Hal ini disebabkan karena obat dimasukkan dalam objek perlindungan HKI dalam ruang lingkup Paten, sehingga obat dipandang sebagai bagian dari industrial.

\section{Pendistribusian Obat}

Negara menjamin bahwa layanan kesehatan setiap warga negara menjadi optimal tanpa memandang status sosial individu. Layanan kesehatan yang seharusnya disediakan oleh negara, termasuk jaminan ketersediaan obat-obatan lengkap dalam

${ }^{33}$ Sjachran Basah, Eksistensi dan Tolok Ukur Badan Peradilan Administrasi di Indoenesia, Alumni, Bandung, 1985, h.3.

${ }^{34}$ Endang Purwaningsih, Seri Hukum Hak Kekayaan Intelektual Hukum Paten, Mandar Maju, Bandung, 2015, h. 102. 
jumlahyang cukup, kualitas terjamin, kualitas bagus, terjangkau dan mudah diakses oleh masyarakat yang membutuhkan. ${ }^{35}$

Setiap negara memiliki sistem distribusinya sendiri yang ditentukan oleh pemerintah. Hal ini didasari oleh paradigma kesehatan komunitas yang diikuti oleh negara dan cara pemerintah memandang obat itu apakah itu murni dianggap sebagai produk ekonomi, dianggap sebagai bagian dari pelaksanaan kesehatan sistem oleh negara atau kombinasi dari kedua konsep itu. Konsep ketiga biasanya diadopsi oleh negara berkembang sebagai solusi untuk memenuhi kebutuhan masyarakat yang biasanya ditempatkan dalam varietas stratifikasi kesejahteraan. Sistem ini membedakan obat murni dianggap sebagai produk ekonomi yang dijual sesuai untuk mekanisme pasar, tetapi pemerintah juga menyediakan obat dalam implementasi kesehatan sistem oleh negara yang mudah diakses oleh komunitas dengan harga murah. ${ }^{36}$

1) Prosedur Pendistribusian obat di Indonesia:

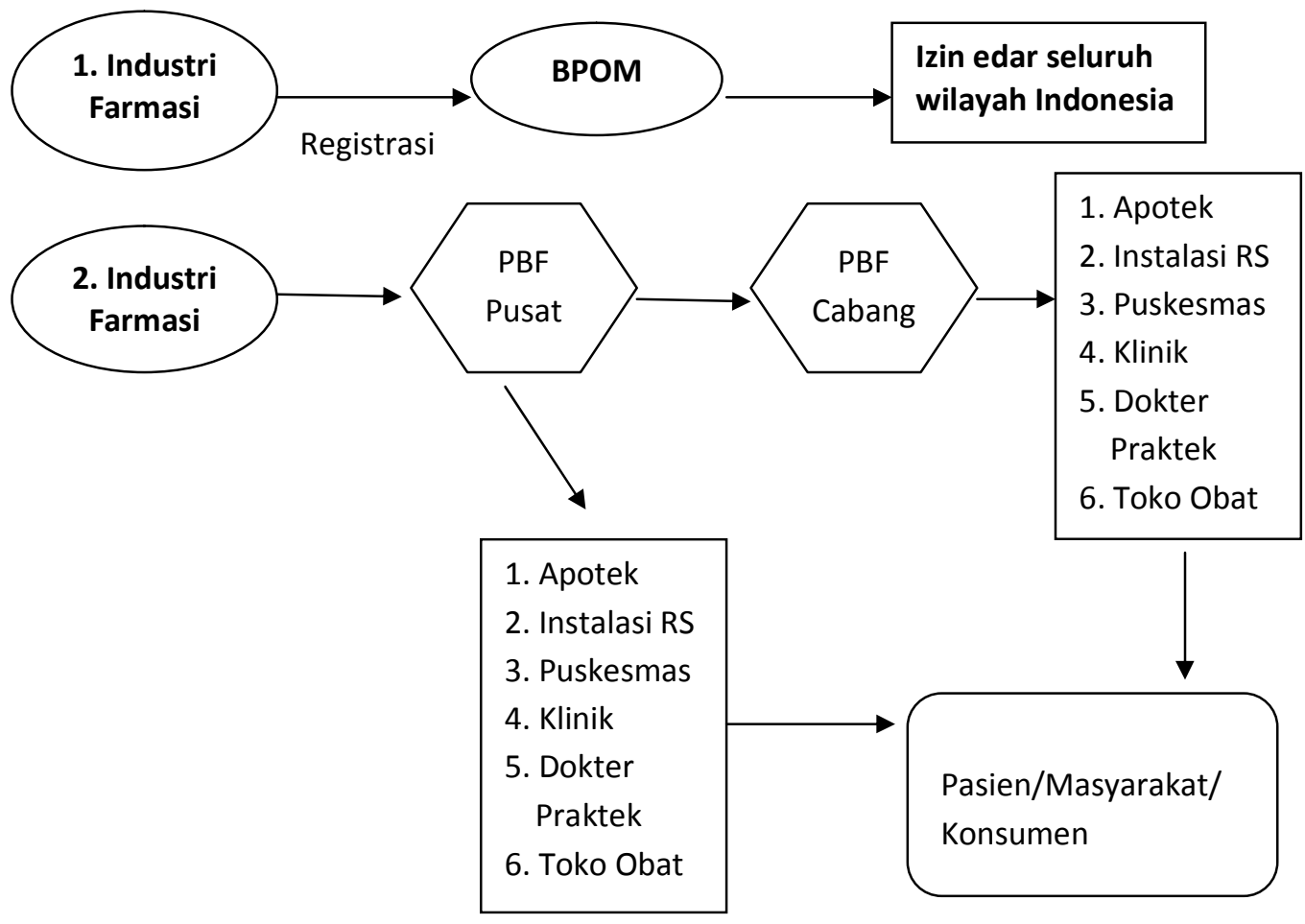




\section{Keterangan Model :}

a) Industri farmasi harus melakukan registrasi obat yang diajukan ke Kepala Badan BPOM untuk mendapatkan izin edar obat keseluruh wilayah Indonesia, hal ini diatur dalam Permenkes No. 1010/Menkes/Per/XI / 2008 tentang Registrasi Obat. ${ }^{37}$

b) Setelah mendapatkan persetujuan registrasi, maka obat didistribusikan melalui Pedagang Besar Farmasiyg disingkan PBF. PBF lah yang bertugas menyalurkan obat ke apotek, instalasi farmasi rumah sakit, puskesmas, klinik, toko obat, dan dokter praktek.

2) Kesenjangan dalam Pendistribusian Obat

Keterbatasan dalam mengakses obat tidak hanya dikarenakan keterbatasan kemapuan masyarakat dalam membeli obat dan tapi juga dikarenakan distribusi obat yang tidak merata. salah satu kendala pendistribusian dikarenakan untuk beberapa jenis obat, PBF sebagai penyimpan, mengadaan, dan penyalur obat harus menyediakan gudang penyimpanan obat yang memiliki pendingin untuk menjaga kualitas obat tetap terjaga serta menyediakan apoteker untuk bertanggung jawab dalam pendistribusian obat. Keterbatasan fasilitas semacam ini membatasi PBF untuk mendistribusikan obat ke daerah-daerah terpencil dan belum terjangkau, sehingga aksesnya menjadi sulit dan harga menjadi mahal. ${ }^{38}$

Kurangnya kesadaran untuk mengambil langkah-langkah untuk mengurangi tingkat kesenjangan ini menyebabkan kesalahan dalam membuat kebijakan distribusi obat. Pendistibusian obat di Indonesia seharusnya di tempatkan dalam perspektif implementasi kesejahteraan masyarakat dan tidak hanya dilihat sebagai kegiatan ekonomi karena setiap komponen dalam sistem distribusi obat dimulai dari industri farmasi ke konsumen sehingga kepentingan mereka terlindungi. ${ }^{39}$

\footnotetext{
${ }^{37}$ Industri Farmasi adalah badan usaha yang memiliki izin dari Menteri Kesehatan untuk melakukan kegiatan pembuatan obat atau bahan obat.

${ }^{38}$ Aktieva Tri Tjitrawati, Op Cit,. h. 10.

${ }^{39} \mathrm{Ibid}$.
} 


\section{Perbandingan Hak Atas Akses Obat Bagi Masyarakat Dalam Perjanjian Internasional Dan Peraturan Paten Di Indonesia.}

1. Perjanjian Internasional

World Trade Organization (WTO)

Isu kesehatan publik dengan perdagangan internasional, khususnya akses masyarakat terhadap harga obat yang terjangkau, telah mendapatkan perhatian khusus dari negara anggota Organisasi Perdagangan Dunia/World Trade Organization (WTO). Salah satu penyebab harga obat menjadi tinggi dikarenakan adanya perlindungan paten yang terdapat diTrade Related Aspects of Intellectual Property Rights (TRIPs) sebagai salah satu perjanjian cakupan WTO.

Organisasi Perdagangan Dunia (WTO) adalah organisasi Internasional yang berkaitan dengan aturan perdagangan antar negara pada tingkat global atau hampir global. Pada pusat organisasi adalah perjanjian bahwa anggota yang terdiri dari sebagian besar perdagangan dunia negara atau serikat pabean (158 anggota pada Juli) 2008) bernegosiasi dan menandatangani. Perjanjian ini menyediakan aturan dasar hukum untuk perdagangan internasional. WTO keanggotaan mengharuskan negara untuk mengadopsi ketentuan dua puluh enam perjanjian yang ada dan mengamanatkan itu undang-undang nasional anggota sesuai dengan standar global.

Pada tingkat internasional, ancaman paten terhadap akses kesehatan publik bertambah nyata ketika World Trade Organization (WTO) memasukkan HKI sebagai salah satu perjanjian yang harus diikuti oleh negara-negara pesertanya. The Agreement on Trade-Related Aspects of Intellectual Property Rights (TRIPs) adalah perjanjian internasional di bawah administrasi WTO yang menetapkan standar minimum untuk berbagai peraturan $\mathrm{HKI}$, termasuk paten, di masing-masing negara anggotanya. ${ }^{40}$ Penerapan TRIPs pada semua negara anggota WTO menimbulkan perdebatan sengit pada awal pembentukan TRIPs karena level ekonomi dan pembangunan yang berbeda antara negara kaya dan miskin.TRIPs mewajibkan seluruh negara anggotanya

\footnotetext{
${ }^{40}$ Ancaman Paten terhadap kesehatan Publik, Universitas Katolik Indonesia Atmajaya, https://m.atmajaya.ac.id/Web/KontenUnit.aspx?gid=artikel-hki\&ou=hki\&cid=ancaman-

paten-terhadap-kesehatan-publik-dan-safeguards-TRIPs, diakses pada tanggal 21 Juli 2018, pukul 21.00 W.I.B.
} 
untuk membuat aturan-aturan mengenai hak kekayaan intelektual. ${ }^{41}$ TRIPs Agreement mensyaratkan adanya keseimbangan antara hak pemegang paten dengan kewajiban kepada masyarakat dengan cara tiap negara dapat menyesuaikan syarat-syarat tersebut dalam peraturan pelaksanaan nasionalnya masing-masing sepanjang tidak bertentangan dengan ketentuan yang berlaku di TRIPs.

\section{Trade Related Aspects of Intellectual Property Rights (TRIPs)}

Isu utama yang membuat kesepakatan TRIPs menjadi amat kontroversial sehingga memaksa delegasi WTO untuk melakukan perundingan tambahan adalah dampak TRIPS pada akses pada obat, terutama di negara miskin dan terutama untuk penyakit-penyakit epidemik seperti AIDS, TBC, flu burung dan malaria.Ada tiga alat penting dalam TRIPs yang dapat digunakan setiap negara anggota WTO untuk melindungi kesehatan masyarakat yaitu: impor paralel (pasal 28 dan 31), lisensi wajib dan penggunaan oleh pemerintah (pasal 30). Ketiganya dapat digunakan untuk mengabaikan atau merundingkan ulang paten dan royalti bila suatu negara menghadapi masalah penyakit epidemi.

Namun ketika beberapa negara misalnya Afrika Selatan hendak menerapkan impor paralel atau pemanfaatan oleh pemerintah, mereka mendapatkan tekanan bilateral dari negara-negara maju dan pabrik obat. Hal ini mengundang protes dan kecaman di seluruh dunia sehingga mendorongkan agenda kaji ulang mengenai ketentuan tersebut di WTO. Masalah TRIPS dan kesehatan dianggap sedemikian penting sehingga Badan PBB untuk Kesehatan (WHO) juga angkat bicara. Dokumen WHO Action Programme on Essensial Drugsmengatakan: "setiap negara perlu membatasi pelaksanaan hak eksklusif dalam hukum patennya, terutama dengan menerapkan lisensi wajib serta impor paralel”.

TRIPs sendiri sebenarnya telah diatur beberapa model fleksibilitas terkait paten yang dapat diaplikasikan terhadap obat, yakni impor paralel, lisensi wajib dan pelaksanaan paten oleh pemerintah. ${ }^{42}$ Fleksibilitas tersebut kemudian ditegaskan

\footnotetext{
${ }^{41}$ Risa Amrikasari, Peran TRIPs dalam Perlindungan Kekayaan Intelektual, http:/ / www. bukumonline.com/ klinik/ detail/ lt592407520f6f7/peran-TRIPs-iagreement-i-dalam-perrlindunganbak-kekayaan-intelektual, diakses pada tanggal 16 September 2018, pukul 07.25 W.I.B.

${ }^{42}$ Carlos Correa, Implications of Doha Declaration on The TRIPs Agreement and Public Health, WHO, Jenewa, Swiss, 2002, h. 13.
} 
kembali dalam Deklarasi Doha tentang Perjanjian TRIPs dan Kesehatan Masyarakat tahun 2001 serta putusan Dewan TRIPs mengenai Implementasi Paragraf 6 Deklarasi Doha. Salah satu model fleksibilitas TRIPs terkait paten terhadap obat yang lazim digunakan negara-negara saat ini adalah lisensi wajib memungkinkan pemberian izin kepada perusahaan, perwakilan pemerintah atau pihak lain untuk menggunakan paten tanpa kesepakatan atau izin pemegang paten. ${ }^{43}$

\section{Deklarasi Doha}

Tujuan utama dalam deklarasi Doha yang di usung oleh negara berkembang dan lembaga swadaya masyarakat untuk mencari keseimbangan antara kepentingan pemegang hak paten yaitu inventor dan hak kesehatan masyarakat terutama negara berkembang dan negara terbelakang. Doha dirancang untuk menyelesaikan masalah yang timbul akibat kelemahan TRIPs khususnya dalam akses bidang kesehatan masyarakat. Secara garis besar Deklarasi Doha berisi tujuh paragraf yang dapat dibagi menjadi tiga bagian, yaitu paragraf pertama sampai empat merupakan bagian pendahuluan, bagian kedua adalah konfirmasi atas interpretasi terhadap beberapa ketentuan dalam TRIPs yang terdapat dalam paragraf lima dan bagian ketiga adalah mengenai operasionalisasi deklarasi yang terdapat dalam paragraf enam dan tujuh. ${ }^{44}$

Namun hingga saat ini Deklarasi Doha masih belum dijadikan suatu perjanjian. Hal ini tejadi karena perlindungannya yang lebih memprioritaskan hak kesehatan masyarakat sehingga memungkinkan adanya pengaturan akses obat yang akan mengurangi keleluasaan dalam memproduksi obat dan keuntungan dari perusahaan obat yang dimiliki negara maju.

\section{Trade Related Aspects of Intellectual Property Rights-Plus (TRIPs-Plus)}

TRIPs Plus adalah tingkat perlindungan norma yang lebih tinggi yang diminta oleh negara-negara maju yang tidak ditentukan oleh TRIPs WTO. Meskipun diberi nama TRIPs Plus, mereka tidak secara resmi terkait dengan TRIPs. Negara berkembang yang menjadi anggota FTA berada dibawah tekanan untuk

\footnotetext{
${ }^{43}$ Carlos Correa, Integrating Public Health Concerns into Patent Legislation in Developing Countries, the South Centre, Swiss, 2000, h.93.

${ }^{44}$ Ibid, h.5
} 
memberlakukan ketentuan yang lebih ketat dalam UUP mereka. TRIPS plus akan mengurangi persaingan dan menyebabkan kenaikan harga obat-obatan yang mempengaruhi keamanan kesehatan di negara-negara berkembang dan negara miskin. ${ }^{45}$

TRIPs plus menolak adanya akses data ekslusif yang dimiliki oleh produsen obat paten oleh produsen obat generik. TRIPs plus menormakan perlindungan terhadap eksklusivitas data. Ekslusifitas data adalah perlindungan data uji klinis yang dikirimkan ke badan pengawas untuk membuktikan keamanan, kualitas, dan kemanjuran obat baru, serta mencegah produsen obat generik untuk mengandalkan data ini dalam aplikasi mereka sendiri. Ekslusifitas data seperti itu akan menghentikan negara-negara berkembang menggunakan data ini ketika mengajukan permohonan lisensi untuk obat generik. ${ }^{46}$

\section{Bilateral Free Trade Agreement (BFTA)}

Bilateral Free Trade Agreement (BFTA) menjadi salah satu bentuk TRIPs Plus yang diambil oleh negara maju dan negara berkembang untuk mengimplementasikan norma-norma HKI yang terdapat di negara maju kepada negara berkembang. Perjanjian TRIPs menetapkan kerangka kerja pengaturan Inernasional untuk perlindungan dan penegakan HKI, tetapi mekanisme perdagangan bilateral memastikan lebih tinggi standar perlindungan HKI diluar yang ditentukan dalam perjanjian TRIPs. Ketentuan TRIPs Plus secara luas disepakati di BFTA antara negara maju dan negara berkembang termasuk Indonesia, yang berarti norma-norma HKI terkandung dalam TRIPs adalah norma yang cocok untuk melindungi negar maju seperti Amerika Serikat, Jepang, negara-negara Eropa dan lain-lainnya. ${ }^{47}$

Perbedaan antara Bilateral Free Trade Agreement (BFTA) dan Trade Related Aspects of Intellectual Property Rights (TRIPs).

\footnotetext{
${ }^{45}$ Tojo Jose, https:// www.indianeconomy.net/asplclassroom/what-is-TRIPs-plus-what-is-dataexclusivity/, diakses pada 08 Nopember 2018, pukul 10.24 W.I.B.

${ }^{46}$ Ibid.

${ }^{47}$ Nurul Barizah, TRIPs-Plus Provision On Patent Under Indonesia's Bilateral Free Trade Agreement, Jurnal Hukum Ius Quia Iustum No. 3 Vol.21 Juli 2014 h. 3.
} 
a. Penggunaan lisensi wajib.

Di bawah TRIPS, pemerintah dapat mengeluarkan lisensi wajib untuk mendapatkan obat, generik, sedangka BFTA membatasi penggunaan lisensi wajib untuk keadaan darurat, obat anti-trust, dan kasus penggunaan nonkomersial publik.

b. Uji perlindungan data.

TRIPS hanya mensyaratkan bahwa data uji harus dilindungi dan menentang penggunaan komersial yang tidak adil. BFTA mengharuskan pemerintah untuk menjamin eksklusif penggunaan data uji untuk produk farmasi selama lima tahun,

c. Ketentuan paten

TRIPs perlindungan paten selama dua puluh tahun. BFTA mengamanatkan perluasanperlindungan paten melampaui dua puluh tahun.

d. Penggunaan impor paralel

Impor paralel memungkinkan pemerintah untuk mengimpor obat-obatan yang telah ditempatkan di pasar lebih murah di pasar luar negeri, yang dapat membantu mengurangi harga obat, sedangkan BFTA memungkinkan pemegang paten untuk mencegah impor paralel.

e. Pengecualian Bolar.

TRIPs tidak membatasi perusahaan generik mungkin dari memulai proses memasuki pasar baru sebelum paten berakhir. Produsen generik sering mengambil tindakan ini sehingga mereka dapat siap untuk menjual produk mereka segera setelah paten berakhir. BFTA mencegah persetujuan pemasaran obat generik obat selama masa paten tanpa persetujuan dari pemegang paten. ${ }^{48}$

\section{Pengaturan Paten di Indonesia}

Pengaturan mengenai paten di Indonesia telah mengalami empat kali perubahan yaitu UU No. 6 Tahun 1989 dirubah menjadi UU No. 1 Tahun 1997, dirubah lagi menjadi UU No. 14 Tahun 2001 dan terakhir dirubah menjadi UU No.

${ }^{48}$ Fink and Reichenmiller, Tightening TRIPS: The Intellectual Property Provisions of Recent US Free Trade Agreement, Washington DC, 2005, h. 3. 
13 Tahun $2016 .{ }^{49}$ Landasan filosofis merupakan nilai-nilai moral atau etika dari bangsa Indonesia. Moral dan etika pada dasarnya berisi nilai-nilai yang baik, merupakan pandangan dan cita hukum bangsa Indonesia berakar pada Pancasila yang dijunjung tinggi, didalamnya terkandung nilai kebenaran, keadilan dan kesusilaan serta berbagai nilai lainnya yang dianggap baik dalam menata kehidupan bermasyarakat berbangsa dan bernegara. Undang-undang selalu mengandung norma-norma hukum yang diidealkan (ideal norm) oleh suatu masyarakat menuju cita-cita luhur kehidupan bermasyarakat dan bernegara yang hendak diarahkan. Karena itu, undang- undang dapat digambarkan sebagai cermin dari cita-cita kolektif suatu masyarakat tentang nilai-nilai luhur yang hendak diwujudkan dalam kehidupan sehari-hari melalui pelaksanaan undangundang yang bersangkutan dalam kenyataan. Oleh sebab itu, citacita sebagai landasan filosofis yang terkandung dalam undang-undang itu hendaklah sejalan dengan cita-cita filosofis yang dianut masyarakat bangsa Indonesia itu sendiri. ${ }^{50}$ Bertitik tolak dari uraian tersebut di atas maka landasan filosofis dalam melakukan perubahan terhadap Undang-Undang Nomor 14 Tahun 2001 tentang Paten, yang merupakan hak eksklusif yang diberikan oleh Negara kepada inventor dan/atau pemegang hak, dan merupakan intangibleassets (benda tidak berwujud) yang disamakan dengan barang bergerak yang dapat dialihkan hak kebendaannya, atau dimanfaatkan untuk jangka waktu tertentu oleh pihak lain melalui perjanjian lisensi dan pembayaran royalti. Selain itu karena paten sebagai barang bergerak yang tidak berwujud juga dapat dialihkan dengan cara jual-beli, hibah, pewarisan, putusan pengadilan, atau ketentuan hukum lain yang dibenarkan oleh undangundang. ${ }^{51}$ Namun proses revisi UUP dan kemudian implementasinya, dilakukan secara terburu-buru, tanpa kajian tentang manfaat dan risiko jangka panjang dan tanpa melibatkan partisipasi masyarakat. Baik DPR maupun pemerintah telah menyepakati hak paten atas bahan hayati, melemahkan perlindungan terhadap kearifan adat, melemahkan hak petani atas benih dan melemahkan akses pada obat bagi kaum miskin.

\footnotetext{
${ }^{49} \mathrm{OK}$ Saidin, Loc Cit.

${ }^{50}$ Bagir Manan, Dasar-Dasar Perundang-Undangan di Indonesia, Gajah Mada University Press, Yogyakarta, 1991, h. 14

${ }^{51}$ Rindia Fanny K, Reformasi Peraturan Paten di Indonesia, Jurnal UNNES, Vol. 2 No. 1, Tahun 2016.
} 
Tetapi Indonesia juga salah satu dari sedikit negara yang menggunakan fleksibilitas TRIPS melalui PP no. 27/2004 tentang Tata Cara Pelaksanaan Paten untuk Penggunaan Pemerintah. Ini diikuti Kepres No.83/2004 mengenai ijin memproduksi obat anti retroviral untuk AIDS dengan memberikan kompensasi amat kecil kepada pemegang paten yaitu 0,5\%. Saat menghadapi pandemi flu burung, seharusnya pemerintah juga bisa menempuh langkah yang sama tapi tidak melakukannya tanpa alasan yang jelas. ${ }^{52}$

Deklarasi doha menyediakan ketentuan yang dapat membantu negara-negara berkembang dan terbelakang untuk mengatasi dampak perlindungan paten obat di sektor kesehatan yang berasal dari perjanjian TRIPs seperti Bolar Provision, Import Paralel, Lisensi Wajib dan pelaksanaan paten oleh Pemerintah. Ketiga ketentuan ini telah diadopsi oleh UUP terbaru yaitu Undang-undang No. 13 Tahun 2016. Lisensi Wajib dalam UUP diatur pada pasal 81 hingga pasal 107, elaksanaan paten oleh pemerintah di UUP diatur dalam pasal 109 hingga pasal 120, Impor Paralel dan bolar provision diatur dalam pasal 167 .

\section{Perbandingan TRIPs dan Undang-undang No. 13 Tahun 2016 tentang Paten}

\begin{tabular}{|c|c|c|}
\hline Bidang & TRIPs & UUP \\
\hline & $\begin{array}{l}\text { - Pemohon harus memohon kepada } \\
\text { pemegang paten untuk } \\
\text { mendapatkan lisensi, bila tidak } \\
\text { berhasil, konsisten dengan Pasal } \\
\text { 31(b) } \\
\text { - Proses pemberian lisensi (e.g } \\
\text { 85,88,92), konsisten dengan Pasal } \\
\text { 31(b) } \\
\text { - Dalam bentuk non-ekslusif, hanya } \\
\text { untuk pasar domestik dan } \\
\text { pembayaran royalti yang sesuai }\end{array}$ & $\begin{array}{l}\text { - Dasar hukum pasal 81-107 } \\
\text { - Permohonan diajukan karena tidak } \\
\text { mendapatkan izin lisensi oleh } \\
\text { pemegang hak paten. (pasal 82-86) } \\
\text { - Proses pemberian, penundaan atau } \\
\text { penolakan (pasal 87-93). } \\
\text { - Bersifat Non-Eksklusif (pasal 81) } \\
\text { - Hal ini menunjukkan peraturan di } \\
\text { Indonesia sesuai dengan TRIPs. }\end{array}$ \\
\hline
\end{tabular}

${ }^{52}$ Hira Jhamtani, Loc Cit. 


\begin{tabular}{|c|c|c|}
\hline & $\begin{array}{l}\text { (pasal 84) adalah contoh pasal } \\
\text { sesuai dengan ketentuan pasal } 31 \\
\text { (d),(f) dan (h). }\end{array}$ & \\
\hline $\begin{array}{l}\text { Pelaksanaan } \\
\text { Paten oleh } \\
\text { Pemerintah }\end{array}$ & $\begin{array}{l}\text { - Government Use dibenarkan oleh } \\
\text { pasal 31, pasal tersebut mengijinkan } \\
\text { untuk menggunakan paten tanpa } \\
\text { ijin dari pemegang paten } \\
\text { berdasarkan kondisi tertentu, } \\
\text { misalnya perlindungan terhadap } \\
\text { kepentingan umum } \\
\text { - Mensyaratkan bentuk } \\
\text { permohonan terhadap government } \\
\text { use harus bersifat non eksklusif, } \\
\text { adanya ganti kerugian yang layak } \\
\text { (royalti) kepada pemegang paten } \\
\text { serta adanya otoritas yang meninjau } \\
\text { ulang pelaksanaan melalui sebuah } \\
\text { mekanisme hukum yang } \\
\text { independen. } \\
\text { - Government use hanya } \\
\text { berhubung dengan keadaan darurat } \\
\text { dan mendesak. }\end{array}$ & $\begin{array}{l}\text { - Dasar Hukum pasal 109-120 } \\
\text { - Pemerintah dapat melaksanakan } \\
\text { sendiri Paten di Indonesia } \\
\text { berdasarkan: } \\
\text { a. berkaitan dengan pertahanan dan } \\
\text { keamanan negara } \\
\text { b. kebutuhan sangat mendesak } \\
\text { untuk kepentingan masyarat. }\end{array}$ \\
\hline $\begin{array}{l}\text { Bolar } \\
\text { Provision }\end{array}$ & $\begin{array}{l}\text {-Menurut Pasal 30, pengecualian } \\
\text { paten tidak dilarang sepanjang tidak } \\
\text { bertentangan dengan pemanfaatan } \\
\text { paten secara normal dan tidak } \\
\text { bertentangan dengan kepentingan } \\
\text { yang sah dari pemegang paten. } \\
\text { - Penggunaan obat-obatan melalui } \\
\text { uji coba dan produksi ini, } \\
\text { diperbolehkan hanya untuk }\end{array}$ & $\begin{array}{l}\text { - Mengijinkan perusahaan pembuat } \\
\text { obat generik bagi yang sudah } \\
\text { dipatenkan, 5th sebelum } \\
\text { perlindungan paten obat berakhir. } \\
\text { - memungkinkan perusahaan } \\
\text { generik lokal melakukan pengujian } \\
\text { dan mempersiapkan produk versi } \\
\text { generik dari obat yang dipatenkan } \\
\text { dengan ntuk mempersiapkan ijin }\end{array}$ \\
\hline
\end{tabular}




\begin{tabular}{|c|c|c|}
\hline & $\begin{array}{l}\text { kegiatan dan keperluan perolehan } \\
\text { ijin edar dan bukan ditujukan untuk } \\
\text { kepentingan komersial. }\end{array}$ & $\begin{array}{l}\text { edar obat generik tersebut. } \\
\text { - }\end{array}$ \\
\hline & $\begin{array}{l}\text {-Pasal 28menyatakan bahwa } \\
\text { pemegang paten memiliki hak } \\
\text { eksklusif untuk melarang pihak } \\
\text { ketiga tanpa seijinnya memakai, } \\
\text { menggunakan, mejual termasuk } \\
\text { juga mengimpor produk yang } \\
\text { terkait dengan paten tersebut. } \\
\text { - Dapat disimpulkan bahwa pada } \\
\text { dasarnya TRIPs tidak } \\
\text { melarang adanya praktek parallel } \\
\text { import. Kebijakan untuk melarang } \\
\text { atau membolehkan adanya parallel } \\
\text { import diserahkan pada hukum } \\
\text { nasional masing-masing negara } \\
\text { yang bersangkutan. }\end{array}$ & $\begin{array}{l}\text { - Dasar hukum : pasal } 167 \text { (b) } \\
\text { - Impor paralel didefinisikan sebagai } \\
\text { impor sebuah produk farmasi yang } \\
\text { yang telah dipatenkan dan } \\
\text { dipasarkan di negara lain. } \\
\text { - Tujuannya untuk menjamin adanya } \\
\text { harga yang wajar dan memenuhi rasa } \\
\text { keadilan dari produk farmasi yang } \\
\text { sangat dibutuhkanbagi kesehatan } \\
\text { manusia. Ketentuan ini dapat } \\
\text { digunakan apabila harga suaru } \\
\text { produk di Indonesia sangat mahal } \\
\text { dibanding dengan harga yang telah } \\
\text { beredar secara sah di pasar } \\
\text { Internasional (penjelasan pasal 167). }\end{array}$ \\
\hline
\end{tabular}

Dari perbandingan yang penulis buat diatas, maka terlihat bahwa UUP Indonesia telah sesuai dengan ketentuan yang ada di TRIPs. Namun untuk melaksanakan ke-empat akses obat tersebut peraturan di Indonesia masih belum memadai karena:

\begin{tabular}{|c|l|l|}
\hline Bidang & \multicolumn{1}{|c|}{ Permasalahan } & \multicolumn{1}{|c|}{ Saran } \\
\hline \multirow{3}{*}{ Impor } & - Peraturan kurang jelas mengenai & - Meninjau ulang lembaga yang \\
para pihak yang bertanggung jawab & bertanggung jawab \\
Paralel & dalam pelaksanaannya & - Menyediakan pengertian yang \\
& -Daftar target obat yang dibutuhkan & spesifik mengenai impor \\
& belum tersedia. & paralel. \\
\hline
\end{tabular}




\begin{tabular}{|c|l|l|}
\hline $\begin{array}{c}\text { Bolar } \\
\text { Provision }\end{array}$ & $\begin{array}{l}\text {-Penjelasan kegiatan yang dilakukan } \\
\text { kurang jelas. } \\
\text {-Daftar obat generik belum tersedia. }\end{array}$ & $\begin{array}{l}\text { Menyediakan PP untuk } \\
\text { pelaksanaan Bolar provision. }\end{array}$ \\
\hline $\begin{array}{c}\text { Lisensi } \\
\text { wajib }\end{array}$ & $\begin{array}{l}\text { Pasal yang mengatur royalti belum } \\
\text { ada }\end{array}$ & $\begin{array}{l}\text { Membuat kategori jumlah } \\
\text { royalti dan kriteriapemberian } \\
\text { royalti }\end{array}$ \\
\hline $\begin{array}{c}\text { Pelaksanaan } \\
\text { Paten oleh } \\
\text { Pemerintah }\end{array}$ & Prosedur kasasi belum jelas. & $\begin{array}{l}\text {-menyediakan ketentuan kasasi } \\
\text { lebih jelas untuk pemegang } \\
\text { panten jika kalah di pengadilan } \\
\text { niaga. }\end{array}$ \\
\hline
\end{tabular}

Permasalahan ini harus segera diatasi, agar akses obat yang mudah dapat membantu menurunkan harga obat, terpenuhinya hak pemegang paten obat atas royalti yang diterima, dan hak kesehatan masyarakat. Jika pemerintah tidak mampu mengatasi permasalahan ini maka tidak akan terwujud rasa keadilan dan kesejahteraan pemegang paten dan masyarakat sebagai konsumen.

\section{Penutup}

Dari uraian tersebut di atas, maka yang dapat disimpulkan adalah :

1. Hak atas kesehatan berupa akses obat merupakan bagian dari hak Konstitusional dan hak sebagai warga negara karena merupakan hak dasar yang dituangkan dalam konstitusi sebagai hak yang dijamin dalam dan oleh Undang-Undang Dasar (UUD) 1945. Monopoli obat paten mengakibatkan akses obat dan harga obat paten tidak terkontrol. Hal ini seharusnya tidak terjadi karena tidak memenuhi rasa keadilan terhadap masyarakat dan tidak memenuhi hak sebagai warga negara.Perlindungan paten obat merupakan masalah kesehatan masyarakat yang serius. Kebijakan untuk melindungi paten obat harus seimbang dengan perjanjian TRIPs dan deklarasi Doha agar tujuannya menyediakan obat yang lebih murah dan keinginan pemerintah memberikan perlindungan yang memadai untuk paten obat bisa tercapai.

2. TRIPs, Deklarasi Doha dan UUP merupakan bentuk keseriusan negara dalam memperjuangkan hak pemegang paten dan hak kesehatan masyarakat. TRIPs 
lebih dominan melindungi hak negara maju sebagai pemegang hak Paten dan Deklarasi Doha di lahirkan untuk melindungi hak kesehatan masyarakat dikarenakan sulitnya akses obat dan harga obat yang mahal. Pemerintah harus mampu memenuhi hak pemegang paten dan hak kesehatan masyarakat dengan mengeluarkan peraturan yang dapat mendukung terselenggaranya lisensi wajib, Bolar Provision, Impor paralel dan paten oleh pemerintah.

\section{DAFTAR PUSTAKA}

\section{BUKU}

Apeldoorn, L.J. Van, Pengantar Ilmu Hukum, diterjemahkan oleh Oetarid Sadino, Pradnya Paramitha, Jakarta, 2001

Asshiddiqie, Jimly, Konstitusi \& Konstitusionalisme Indonesia, Edisi Revisi, Konstitusi Press, Jakarta, 2005

Astrinia, Arianne dan Prasetyo, Brian Amy, Perbandingan Konsep Pelanggaran Paten di Indonesia dan Amerika Serikat : Studi Kasus Pelanggarna Paten Obat, Jurnal Hukum FH UI, 2014

Basah, Sjachran, Eksistensi dan Tolok Ukur Badan Peradilan Administrasi di Indoenesia, Alumni, Bandung, 1985

Correa, Carlos, Implications of Doha Declaration on The TRIPs Agreement and Public Health, WHO, Jenewa, Swiss, 2002

-------, Carlos, Integrating Public Health Concerns into Patent Legislation in Developing Countries, the South Centre, Swiss, 2000

Daniels, Norman, Just Health., Cambridge: Cambridge University Press, 2009

Fink and Reichenmiller, Tightening TRIPS: The Intellectual Property Provisions of Recent US Free Trade Agreement, Washington DC, 2005

Friedrich, Carl Joachim, Filsafat Hukum: Perspektif Historis, Nuansa, Bandung, 2004

Hadjon, Phillipus, M, Perlindungan Hukum Bagi Rakyat Indonesia, Bina Ilmu, Surabaya,1987

-------, Philipus M. Perlindungan Bagi Rakyat di Indonesia, Edisi Revisi, Peradaban, Jakarta, 2007

Huijbers, Theo, Filsafat Hukum Dalam Lintas Sejarah, Kanisius, Yogyakarta, 1990

Kurnia, Titon Slamet, Hak Atas Derajat Kesehatan Optimal Sebagai HAM di Indonesia, Alumni, Bandung, 2007

Manan, Bagir, Dasar-Dasar Perundang-Undangan di Indonesia, Gajah Mada University Press, Yogyakarta, 1991

Marzuki, Peter Mahmud, Luasnya Perlindungan Paten, Jurnal Hukum, UII, Vol. 6 No. 12, tahun 1999.

--------, Peter Mahmud, Pengantar Ilmu Hukum, Kencana, Jakarta, 2016

Nasution, Muhammad Syukri Albani, dkk, Hukum Dalam Pendekatan Filsafat, Kencana, Jakarta, 2016 
Nurbani, Salim dan Erlies Septiana, Penerapan Teori Hukum Pada penelitian Tesis dan Disertasi, Raja Grafindo, Jakarta, 2000

Nuryartono, Nunung dan Saparini, Hendri, "Kesenjangan Ekonomi Sosial dan Kemiskinan”, Ekonomi Konstitusi: Haluan Baru Kebangkitan Ekonomi Indonesia, Jakarta, Soegeng Sarjadi Syndicate, 2009

Purwaningsih, Endang, Seri Hukum Hak Kekayaan Intelektual Hukum Paten, Mandar Maju, Bandung, 2015

Rawls, John A, Teory of Justice, Cambridge: The Belknap Press, 2005

------, John, C, att all, Liberty, Equality, and Law, 1st. Cambridge: Cambridge University Press, 1987

$\mathrm{R}$, Munson, Intervention and Refection Basic Issues in Bioethics. 9th. Boston: Cengage Learning, 2012

Saidin, O.K, Aspek bukum Hak Kekayaan Intelektual (intellectual Property Rights), PT. Raja Grafindo Persada, Jakarta, 2015

Soejono dan Abdurrahman,H, 2003, Metode Penelitian Hukum, Rineka Cipta, Jakarta

Tjitrawati, Aktieva Tri, The Just Drug Distribution In The Perspective Of Welfare State, Mimbar Hukum, Volume 25, Nomor 3, Oktober 2013

Usman, Rachmadi, Hukum Hak atas Kekayaan Intelektual : Perlindungan dan Dimensi Hukumnya di Indonesia, Alumni, Bandung, 2003

Wilamarta, Mishardi, Hak Pemegang Saham Monoritas dalam Rangka Good Corporte Gorvernance, Program Pascasarjana Fakultas Hukum Universitas Indonesia, Jakarta, 2002

Yunarto, Nanang, Revitalisasi Obat Generik: Hasil Uji Disolusi Obat Generik Tidak Kalah Dengan Obat Bermerek, Media Litbang Kesehatan Volume XX Nomor 4 Tahun 2010

\section{JURNAL}

Mastur, Perlindungan Hukum Hak Kekayaan Intelektual Dibidang Paten, Jurnal Ilmiah Ilmu Hukum QISTI Vol 6 No. 1 Januari 2012

Mikael Rostila, Social Capital an Health Inequality in European Welfare State, Palgrave Macmillan, 2013, London, h. 10, dalam Aktieva Tri Tjitrawati, The Just Drug Distribution In The Perspective Of Welfare State, Mimbar Hukum, Volume 25, Nomor 3, Oktober 2013

Nurul Barizah, TRIPs-Plus Provision On Patent Under Indonesia's Bilateral Free Trade Agreement, Jurnal Hukum Ius Quia Iustum No. 3 Vol.21 Juli 2014

Rindia Fanny K, Reformasi Peraturan Paten di Indonesia, Jurnal UNNES, Vol. 2 No. 1, Tahun 2016.

\section{INTERNET}

Ancaman Paten terhadap kesehatan Publik, Universitas Katolik Indonesia Atmajaya, https://m.atmajaya.ac.id/Web/KontenUnit.aspx?gid=artikel-

hki\&ou=hki\&cid= ancaman-

paten-terhadap-kesehatan-publik-dan-safeguards-TRIPs, diakses pada tanggal 21 Juli 2018, pukul 21.00 W.I.B.

Risa Amrikasari, Peran TRIPs dalam Perlindungan Kekayaan Intelektual, http:/ / www.bukumonline.com/klinik. / detail/ lt592407520f6f7/peran-TRIPs- 
iagreement-i-dalam-perrlindungan-hak-kekayaan-intelektual, diakses pada tanggal 16 September 2018, pukul 07.25 W.I.B.

Tojo Jose, https://www.indianeconomy.net/asplclassroom/what-is-TRIPs-plus-what-is-dataexclusivity/, diakses pada 08 Nopember 2018, pukul 10.24 W.I.B. 